\title{
Näinkö puhuu sosiokonstruktivisti?
}

Reijo A. Kauppinen (2007). Ihmisen tapa oppia. Johdatus sosiokonstruktiiviseen oppimiskäsitykseen. Jyväskylä: PS-Kustannus.

Oppimiskäsityksissä on tapahtunut selkeä muutos viime vuosikymmenien aikana ja muutos jatkuu edelleen. Viimeistään konstruktivistinen oppimiskäsitys käänsi huomion oppijaan yksilönä ja tämän jälkeen sosiaaliset oppimiskäsitykset, kuten sosiaalinen konstruktivismi, ovat kääntäneet yhä enemmän huomion oppimisen ja merkitysten rakentamisen sosiaaliseen luonteeseen. Sosiaalisesta konstruktivismista eri variaatioineen on tullut opetuksen ja oppimisen tutkimisen, opettajakoulutuksen, opetussuunnitelmien ja yleisen kasvatuskeskustelunkin paradigma, jonka avulla muun muassa perinteisiä opettajajohtoisia tai yksilökeskeisiä opetuksen muotoja on ollut helppo kritisoida ja opetusinnovaatioita viedä läpi.

Käsillä oleva Reijo A. Kauppilan kirja sosiokonstruktivismista liittyy sujuvasti mainittuun murrokseen sen kummemmin kyseenalaistamatta tai kriittisesti pohtimatta, mihin sosiokonstruktivistista tulkintaa oppimisesta oikeastaan tarvitsemme. Joidenkin lukujen yhteyksissä tosin on pohdintakysymyksiä, joiden avulla ehkä sosiokonstruktivismin lähtökohtiakin voi kriittinen lukija peilata, mutta sisällöltään kirja ei tähän suuntaan ohjaa. Tarkasteltavana on siis asioita enemmän yhteen vetävä ja yksinkertaistava kuin auki kirjoittava teos.

Kirjan julkilausuttuna tarkoituksena on johdatella opettajia ja opiskelijoita sosiokonstruktiiviseen oppimiskäsitykseen. Kirja on pyritty laatimaan käytännönläheiseksi ja virikkeitä tarjoavaksi. Käytännönläheisyys näyttää tarkoittavan tässä tapauksessa menettelytapaohjeiden lisäksi nopeaa lukemista, sillä lukujen yhteyteen on koottu paljon tiivistelmiä ja luetteloita. Tiivistelmät ovat joiltain osin toimiviakin - esimerkiksi tunnettujen teoreetikkojen lyhyet esittelyt - mutta usein ne ovat hyvin pelkistäviä asialuetteloita, joissa usein toistuvat samantyyppiset perusasiat: vuorovaikutus, yhteistoiminta, sosiaalisuus jne. Kovin pitkälle asioissa ei siis mennä ja tekstissä on hyvin paljon samantyyppisten asioiden toistoa.

Riippuu luonnollisesti aina kirjoittajan painotuksista ja tulkinnoista, millaisia suuntauksia haluaa sosiokonstruktivismiin kytkeä. Kirjassa käsitellään lähtökohtana konstruktivismia ja konstruktivistista käsitystä oppimisesta. Suuntauksista tuodaan esille lähinnä yksilöllisen ja sosiaalisen konstruktivismin eroavaisuus. Eräänä jaotteluna käytetään toisen käden lähteen perusteella jakoa uuskantilainen, sosiaalinen ja heterogeeninen konstruktivismi. Valitettavasti se ei tästä kirjasta selviä, mitä heterogeenisellä konstruktivismilla lopulta tarkoitetaan. Pieniä epätarkkuuksiakin oppihistorialliseen katsaukseen siis on jäänyt. Ilahduttavaa on kuitenkin pyrkimys tietynlaiseen laaja-alaisuu- teen liittämällä mukaan muun muassa diskurssinäkökulma ja rinnakkaiskäsite sosiaalinen konstruktionismi mikro- ja makrososiaalisine tarkasteluineen.

Yhtenä ratkaisuna kirjassa on kytkeä muutamia tunnettuja ajattelijoita sosiokonstruktiivisen oppimiskäsityksen kehittäjiksi tai vaikuttajahahmoiksi, kuten Gergen, Grundtvig ja Wittgenstein tavallisesti suuntaukseen yhdistettyjen Deweyn ja Vygotskyn lisäksi. Tämä laajentaisi kiinnostavalla tavalla sosiokonstruktivismin oppihistoriallista perspektiiviä, mutta nämä esittelyt ovat jääneet valitettavan suppeiksi. Joten ratkaisu tuntuu hieman keinotekoiselta. Vähintäänkin kirjallisuusviitteitä ja linkkejä lisätiedon lähteille näissä kohdin olisi lukija kaivannut.

Nikolaj F.S. Grundtvig on vaikuttanut valistuksen ajan ajattelijana ja humanistina kansansivistyksen ja kansanopistojen kehittymiseen pohjoismaissa, mikä olisi mahdollistanut kirjaan myös a iku iskasvatuksellisten teemojen mukaan ottamisen ja pohtimisen. Nyt kirja kaikesta huolimatta keskittyy lähinnä koulumaisen opetuksen maailmaan, vaikka sanoja koulu tai oppilas onkin pyritty hienovaraisesti välttämään käyttämällä melko systemaattisesti termejä oppilaitos ja opiskelija.

Kauppilan kirja sisältää paljon positiivisesti sävytettyä ja suostuttelevaa puhetta sosiaalisesta konstruktivismista. Eri käänteissä tästä oppimiskäsityksestä tai siihen nojaavista pedagogisista käytänteistä halutaan luoda suorastaan ylipositiivista kuvaa: ”sosiokonstruktiivinen oppimis- 
käsitys antaa opetukselle puitteet, jotka luovat mielekästä oppimista” (takakansiteksti, s.121), "sosiokonstruktiivinen ote innostaa ottamaan mukaan opetuksen kehittämiseen sosiaalisia työmuotoja...” (s. 119), ”sosiokonstruktivistit korostavat syvällistä ymmärtämistä” (s. 120), "opettaja haluaa nähdä opiskelijan kokonaisena persoonana” (s. 124), "opettajan puhe on innostavaa ja hän eläytyy opiskelijan oppimiseen" (s. 128), "sosiokonstruktiivinen oppimisnäkemys vahvistaa vuorovaikutuksen asemaa pedagogiikassa ja didaktiikassa” (s. 167) ja niin edelleen. Vaikka lukijana itse ei välttämättä sosiokonstruktivismia huonona asiana pitäisikään, alkavat yksipuolisen ylistävät sanavalinnat hieman haitata lukukokemusta. Näinkö puhuu sosiokonstruktivisti? Joten enemmän tilaa olisi kautta linjan kaivannut myös pohdiskelevammalle ja eri näkökulmia arvioivalle tekstille.

Aika ajoin kirjassa myös sorrutaan melko yksioikoiseen päättelyyn oppimisen sosiaalisuu- den tuomasta parannuksesta opetus-oppimisprosessiin. Väitetään usein, että oppiminen tehostuu koska sosiaalinen elementti on läsnä tai sosiaalisuus oppimisessa tuottaa laadukasta oppimista. Tämä on hiukan problemaattista koska sosiaalisuuden huomioiminen merkitsee samalla prosessin monimutkaistumista. Yksilön sijasta työskenteleekin ryhmä tai yksilöä pitäisi ottaa huomioon ryhmän jäsenenä siten, että vuorovaikutus ja roolit aina vaihtelevat. En väitä, että sosiaalisuus välttämättä huonontaisikaan tilannetta, mutta herää kuitenkin kysymys, eikö näin anneta helposti hieman katteettomia lupauksia. Ihmisten välinen sosiaalinen vuorovaikutus oppimistilanteissa ei ole opettajan tai ohjaajan näkökulmasta mikään yksinkertainen tai itsestään toimiva ratkaisu. Ryhmädynamiikka ei aina toimi, eivätkä ryhmän jäsenet aina ota vastuuta tasapuolisesti homman onnistumisesta. Ehkä enemmän olisi voinut tuoda esille myös opettajalta vaadittavaa herkkyyttä sosiaalisten ilmiöiden havaitsemisessa ja oppijoiden kohtaamisessa, jotta ei ajauduta ojasta allikkoon. Tämä kyllä mainitaan, mutta vain ohimennen. Esimerkiksi luku "Sosiokonstruktiivisuus opettajan näkökulmasta” normittaa opettajan roolin tavattoman ennalta määritetyksi toimintaluetteloksi, mikä ehkä kokenutta ryhmänohjaajaa saattaa hieman hymyilyttää.

Kokonaisuutena voidaan todeta, että kirja ei sinänsä tuo mitään uutta keskusteluun sosiaalisesta konstruktivismista tai paikkaa selviä tiedollisia aukkoja kasvatustieteen tai aikuiskasvatuksen alalla. Kirjassa on lähinnä samoihin kansiin koottuna ja tiivistettynä pakettina kirjoittajan valikoimia teoreettisia ja käytännöllisiä näkökulmia. Monet kirjan luvuista ovat tavattoman lyhyitä (2-3 sivua). Siksi se sopiikin oppi- ja käsikirjaksi lähinnä sellaiselle, jolla ei entuudestaan ole perustietoja alueelta. Kirjan eri teemoista löytyykin sitten laajentavaa ja syventävää luettavaa muualta.

Vesa Korhonen 